\title{
Market structure and market access *
}

\author{
Joseph Francois \\ Johannes Kepler Universität (Linz), \\ E) CEPR (London) \\ Ian Wooton \\ University of Strathclyde (Glasgow) \\ \& CEPR (London)
}

April 2009

We explore an issue at the nexus of domestic competition policy and international trade, the interaction between goods trade and market power in domestic trade and distribution sectors. We examine the effect of variations in conditions of domestic competition in services on trade volumes in goods in the cases of both linear and non-linear import demand, including standard form CES-based gravity models of bilateral trade flows. Theory suggests a set of linkages between service-sector pricing and goods trade supported by econometrics involving imports of 22 OECD countries vis-á-vis 69 exporters. Competition in distribution services affects the volume of trade in goods. Additionally, because of interaction between tariffs and pricing, the market structure of the domestic service sector becomes increasingly important as tariffs are reduced. Indeed, depending on the degree of competition, market access concessions on tariffs may be effectively undone in some cases by changes in margins. For exporters, we find that service competition in destination markets matters most for exporters from smaller, poorer countries. Our results also suggest that while negotiated agreements leading to cross-border services liberalization may boost goods trade as well, they may also lead to a fall in goods trade when such liberalization involves FDI leading to increased service sector concentration.

Keywords: import volumes, distribution sector competition, market access, services, trade liberalization, GATS, gravity model

JEL: F12, F13, L16, L8

\footnotetext{
${ }^{*}$ Thanks are due to participants in sessions at CEPR's European Workshop on International Trade and the European Trade Study Group meetings, as well as Bernard Hoekman and a helpful anonymous referee. Address for correspondence: Joseph Francois, Johannes Kepler Universität Linz, Department of Economics, Altenbergerstrae 69, A-4040 LINZ, AUSTRIA. email: joseph.francois@jku.at. www.i4ide.org/francois/
} 


\section{Introduction}

Rules and regulations governing international trade and investment in services are an increasingly important aspect of regional and multilateral trade agreements. International negotiations have focused on regulatory restrictions and barriers to cross-border trade and FDI, while research has emphasized quantifying barriers and exploring the role of traded services as inputs to the manufacturing sector. ${ }^{1}$ In this paper, we emphasize a different role for services in economic integration, highlighting the impact of domestic market power in margin services on goods trade. We thus highlight a set of issues at the nexus of domestic competition policy and international trade, the interaction between international goods trade and domestic market structure in trade and distribution sectors. Analytically, domestic market structure in the service sector has a direct and predictable impact on market access. Our empirical results indicate that these effects can be strong enough in some cases to nullify the promise of expanded market access expected under free trade agreements and customs unions (like the EU's single market program), as well as market access concessions linked to trade preferences and multilateral agreements. ${ }^{2}$ This follows from the determinants of domestic margins applied to goods between the border and final consumers. These margin activities include domestic shipping and logistic services, of course, as well as the wholesale and retail sectors and other links in the distribution chain that carries imported goods to the industrial or household consumer. In a very real sense these services make possible basic interaction between producers and exporters in one country and final consumers in another.

\footnotetext{
${ }^{1}$ This includes Francois and Woerz (2008) Yeaple (2006), Markusen et al (2005), Ito and Krueger (2003), Francois (1990), Jensen, Rutherford, and Tarr (2007), Rutherford and Tarr (2007), and Markusen (1989). Also see the recent survey by Francois and Hoekman (2009).

${ }^{2}$ The literature focused on international aspects of competition policy includes Francois and Horn (2007), Horn and Levinsohn (2001), Hoekman and Mavroidis (1994), Hoekman and Kee (2007), Horn and Movroidis (2001), and Head and Ries (1997). There is also a nascent literature on market access and MFN treatment as defined in the WTO, including Horn and Movroidis (2001) and Horn (2006) on the WTO. However, neither literature is not concerned with the interaction between market access and antitrust policy so much as with open economy aspects of merger policy and the beggar-thy-neighbor potential of antitrust. Closely related to the issues highlighted here is the literature on retail and distribution margins and consumer price passthrough, such as Francois, Manchin, and Norberg (2008).
} 
In exploring these issues, we are highlighting an important though somewhat ignored aspect of the trading system. In the European Union, for example, internal trade in motor vehicles was long hampered by an antitrust exemption for the distribution and servicing of automobiles. (See both Flam and Nordström 1995, and Lutz 2004.) Access to the distribution system was also at the heart of a dispute between the United States and Japan involving Kodak and Fuji film (Nanto 1998). These issues also lurk behind the impact on trade of the retail distribution systems both in Switzerland and Japan, as well as the German experience with retailing cartels and the threat of foreign retail entry to established domestic players. With the elimination of trade barriers for textiles and clothing under the WTO's Agreement on Textiles and Clothing in 2005, the market power of such huge buyers as Wal-Mart may also be an important factor in the transmission of price and quantity changes across global textile and clothing markets. Finally, evidence is emerging that the benefits of non-reciprocal tariff preference schemes may be captured by high-income country importing firms, rather than the low-income country exporter firms for which the programs are intended. (See, for example, Olarreaga and Ozden 2005).

We proceed in this paper as follows. In Section 2 we develop a basic analytical model, involving a domestic distribution sector with market power. It sources both internationally and domestically. We work with this model to examine the impact of imperfect competition in services for the pattern of trade in goods. In Sections 3 and 4, we then examine the impact on gains from trade for both importers and exports. In Section 5, we generalize our analysis of import volumes to the case of non-linear import demand, providing an immediate bridge to gravity models of trade volumes. This is followed in Section 6 by econometric analysis of trade volumes based on a gravity model. We work with data on competition in distribution and sales in several OECD countries, examining econometrically the issues highlighted in the analytical Sections. This involves modeling the interaction between import protection, competition, and the 
pattern of trade. In the context of our gravity model of trade, we find that imperfect competition in the trade and distribution sectors matters most in the context of free trade areas and customs unions, like the European Union. In the EU, we find intraEU trade barriers linked to market structure variation in these sectors higher than the average external EU tariff. We also find that market power translates into reduced trade performance when the size and development (i.e. the bargaining power) of trading partners is unbalanced. We offer concluding comments in Section 7.

\section{The Basic Model}

We focus on the market for imports of a good $q$ that competes with a domestic industry. Our primary interest is in the domestic sale and distribution network which we assume to be less-than-perfectly competitive. It exercises market power in sourcing from both domestic and foreign suppliers, and in sales to final consumers. For expositional purposes, we start with linear functional forms. We later offer a generalization of our trade volume results to more general and non-linear functional forms, like the CES-based import demand functions at the core of the standard gravity model, as a bridge to the empirics in Section 6.

Imports are supplied by competitive, overseas producers. Export and domestic supply are imperfectly elastic. Consequently, due to increasing marginal cost of production, the importing country has some degree of monopoly power in trade. It subjects trade in these goods to an import tax at rate $t$. This creates a wedge between the cif price $p_{\text {cif }}$ and the landed (that is, after duties are paid) import price $p_{m}$. Export supply $q_{m}$ is represented by the inverse supply function (1).

$$
p_{c i f}=a_{m}+b_{m} q_{m}
$$


where $p_{\text {cif }}$ is the export price at the border while landed prices inclusive of tariffs are

$$
p_{m}=\tau p_{c i f} \quad \text { where } \tau \equiv(1+t)
$$

Similarly, domestic supply $q_{d}$ is an increasing function of domestic price, as reflected in the inverse domestic supply schedule (3).

$$
p_{d}=a_{d}+b_{d} q_{d}
$$

Consumer demand for the imported good is defined by the inverse demand curve (4).

$$
p=x-y\left(q_{d}+q_{m}\right)
$$

where $x$ and $y$ are constants defining our demand curve. Interaction between suppliers and final consumers takes place through the services of a domestic service sector that facilitates both the movement of imported goods inland and wholesale and retail distribution, marketing, and any ancillary services required to sell the goods. These services are supplied by a domestic service sector - modeled as a Cournot oligopoly - at constant marginal cost. ${ }^{3}$ The total revenue of a representative firm $i$ in the service sector is:

$$
R_{i}=p\left(q_{m i}+q_{d i}\right)
$$

where $q_{m i}$ and $q_{d i}$ are the quantity of imports sold by a representative intermediary firm $i$. We further assume that there are $n$ identical firms in the service market, each having a share $s=1 / n$ of sales. It proves useful to define the index $\sigma \equiv 1+s$ as an index of market competitiveness that ranges from a value of 1 to 2 . A value of $\sigma=1$ implies perfect competition $(n=\infty)$ while $\sigma=2$ maps to a single firm monopolizing

\footnotetext{
${ }^{3}$ The Cournot approach followed here allows us a direct way to manipulate market structure through induced entry.
} 
distribution $(n=1)$. In equilibrium, we may also have $\sigma=2$ where the service sector acts as a monopolist through perfect collusion in a cartel. Assuming a constant marginal cost $c$, profits of service firm $i$ are:

$$
\pi_{s i}=p q_{i}-\left(p_{m}+c\right) q_{m i}-\left(p_{d}+c\right) q_{d i}
$$

From the first-order conditions for profit maximization, quantities will be

$$
\begin{aligned}
q_{d} & =\left[\tau b_{m} G+y(G-H)\right] / A \\
q_{m} & =\left[b_{d} H+y(H-G)\right] / A \\
q & =\left[\tau b_{m} G+b_{d} H\right] / A
\end{aligned}
$$

where $A \equiv \sigma\left(y b_{d}+\tau b_{m}\left(y+b_{d}\right)\right)>0$,

$$
G \equiv x-c-a_{d}
$$

and $H \equiv x-c-\tau a_{m}$

The split between imported and domestically sourced $q$ will depend on relative import and domestic supply conditions and the tariff rate $\tau .^{4}$

\section{Margins, Tariffs, and Importer Welfare}

It is evident that service-sector firms have power on both sides of the market. Their profits are a function of manipulating double margins. On the input side, the price they pay for imports and domestic goods depends on the total quantity bought and the sensitivity of supply to quantity. Similarly, on the demand side, the price at which they sell to consumers is a function of total quantity brought to market. By restricting their trading, the firms are able to both drive down costs in both supply markets and drive up

\footnotetext{
${ }^{4}$ We are working here with distributors who are willing to source both domestically, internationally, or both. While beyond the focus of this paper, it would also be interesting to explore exclusive distribution networks in the context of open economies.
} 
prices, widening the price-cost margin and boosting profits. ${ }^{5}$ The service-sector margins amount to:

$$
\begin{aligned}
\mu_{d} & =G(\sigma-1) / \sigma+c \\
\mu_{m} & =H(\sigma-1) / \sigma+c
\end{aligned}
$$

Equations (10) and (11) lead directly to the following propositions.

Proposition 1. The Cournot-Nash mark-up on imports for the domestic trade and distribution sectors is a decreasing function of the underlying import tariff.

Proposition 2. The Cournot-Nash mark-up on domestic shipments for the domestic trade and distribution sectors is independent of the underlying import tariff.

The mark-up over marginal cost for imports declines directly with the tariff. Any attempt on the part of the government to exercise its monopoly power in trade eclipses the ability of the service sector to exercise its market power in the same market. What is the interaction between tariffs, market power, and the volume of trade? Differentiating equation (8) with respect to $\tau$ and $\sigma$ yields the following:

$$
\begin{aligned}
\frac{d q_{m}}{d \tau} & =\frac{\left(y+b_{d}\right) \sigma}{A^{2}}\left[b_{d} b_{m}(c-x)-y b_{d} a_{m}+b_{m} a_{d}\right]<0 \\
\frac{d q_{m}}{d \sigma} & =-\frac{q_{m}}{\sigma}<0 \\
\frac{d^{2} q_{m}}{d \sigma^{2}} & >0, \frac{d^{2} q_{m}}{d \sigma d \tau}>0
\end{aligned}
$$

This allows us to make the following propositions.

\footnotetext{
${ }^{5}$ We focus in this section on the full distribution sector margin, or the full difference between actual cost and price. An alternative approach is to explicitly decompose the joint effects of exploiting both the supply and demand margins into a combination of markups (over marginal cost inclusive of oligopsony components) and markdowns. This lends insight into country and sectors variations in passthrough from border prices to consumer prices. See Francois, Manchin, and Norberg (2008).
} 
Proposition 3. Despite the presence of an imperfectly competitive service sector, it remains the case that international trade volumes decline with increases in the import tariff.

Proposition 4. International trade volumes are inversely related to the degree of concentration in the domestic trade and distribution sector, or alternatively the degree of market power exercised in the domestic distribution sector.

Proposition 5. The negative impact of a marginal change in market power on trade volumes is greatest in a zero tariff context, and its marginal impact falls with increased levels of import protection or concentration. Hence, the largest impact of imperfect competition in the service sectors will be observed in zero-tariff countries, free-trade areas, customs unions, and under non-reciprocal trade preferences.

We focus next on the welfare implications of a range of alternative tariff regimes for the importer, and the role played by service-sector competition across these possibilities. Domestic welfare $W$ is comprised of four elements: service sector profits $\pi_{s}$, domestic upstream producer profits $\pi_{d}$, consumer surplus $C S$, and tariff revenue $T R$. Thus:

$$
W=\pi_{s}+\pi_{d}+C S+T R
$$

An explicit expression for service-sector profits is obtained by combining equations (6), (7), and (8).

$$
\pi_{s}=(\sigma-1)\left[b_{d} H^{2}+\tau b_{m} G^{2}+y(G-H)^{2}\right] / \sigma A
$$

As both the service-sector profit margin and the volume of trade decline with the tariff, profits of intermediaries decline as the trade tax is increased. The economic profits of the upstream sector can be measured directly by the area between the domestic supply curve and its intersection with the domestic ex-factory price. Combining equations (3) 
and (7) yields equation (17).

$$
P S=b_{d}\left[\tau b_{m} G+y(G-H)\right]^{2} / 2 A^{2}
$$

Similarly, consumer surplus $C S$ is simply the familiar triangle under the demand curve (4) and above the final demand price $p$. This is represented by equation (18).

$$
C S=y\left(\tau b_{m} G+b_{d} H\right)^{2} / 2 A^{2}
$$

Finally, tariff revenue follows directly from equation (8).

$$
T R=(\tau-1)\left\{a_{d} A+b_{m}\left[b_{d} H+y(H-G)\right]\right\}\left[b_{d} H+y(H-G)\right] / A^{2}
$$

Combining equations (16), (17), (18), and (19) with equation (15) yields welfare as a function of the basic coefficients of our model. If we then take first-order conditions for welfare maximization, we can solve for the optimal tariff as a function of $\sigma$ and the basic demand and supply coefficients of the model. This yields equation (20).

$$
\tau^{*}=\frac{b_{d} y\left[(\sigma-1) J-\sigma a_{m} K\right]-2 b_{m} J K}{\left[a_{m} b_{m}(\sigma-2) K-\sigma b_{m} J-a_{m} b_{d} y\right] K}
$$

where $J \equiv b_{d}(x-c)+a_{d} y$

$$
\text { and } K \equiv b_{d}+y
$$

Figure 1 illustrates domestic welfare and its components for the case of duopoly in the service sector. ${ }^{6}$ As would be expected, consumer surplus declines monotonically with an increasing tariff,while tariff revenue increases to a maximum and then falls. Consequently, for national welfare, there is an interior solution for the optimal tariff, indicated by $\tau^{*}$ in the figure. The loss to the service sector and consumers $\left(\pi_{d}\right.$ and $\left.C S\right)$

\footnotetext{
${ }^{6}$ The coefficient values used in Figures 1 and 2 are $\sigma=1.5, a_{m}=a_{d}=10, b_{m}=b_{d}=2, y=1$, $x=20, c=1$.
} 
from an increasing tariff rate $\tau$ is more than offset to the left of the optimal tariff by the combination of rising domestic profits for upstream producers $\pi_{d}$ and tariff revenue $T R$, while it is only partially offset to the right of the optimal tariff line. The government, in exercising its monopoly power in trade, has the ability to limit the ability of the service sector to extract rents. As has already been established, the profits of the service sector decline with the tariff. Consequently when these rents accrue to domestic agents, the government will wish to moderate its use of the tariff. Indeed, viewed from the perspective of the optimal volume of imports $q_{m}^{*}$ the trade-off is complete. This can be seen by substituting equation (20) into equation (8), which yields equation (21).

$$
q_{m}^{*}=\frac{J-a_{m} K}{2 b_{m} K+b_{d} y}
$$

\section{FIGURE 1 ABOUT HERE}

From equation (21), we can see that from a welfare perspective optimal imports are independent of the degree of market power in the domestic service sector. The coefficient $\sigma$ does not appear in equation (21). In exercising the optimal tariff, the government would seek to target the optimal volume of imports by adjusting the tariff rate $\tau$ to compensate for variations in service sector market power $\sigma$. As a result, the optimal tariff is a strictly decreasing function of the degree of market power in the service sector. This can be shown by differentiating equation (20) with respect to $\sigma$.

$$
\frac{d \tau^{*}}{d \sigma}=-\frac{\left(J-a_{m} K\right)\left(a_{m} b_{d} y+b_{m} \alpha\right)\left(b_{d} y+2 b_{m} \beta\right)}{\left[a_{m} b_{m}(\sigma-2) K-\sigma b_{m} J-a_{m} b_{d} y\right]^{2} K}
$$

The sign of equation (22) is negative whenever $q_{m}^{*}>0$.

These relationships are illustrated in Figure 2, where we plot optimized tariffs, welfare, and quantities for a range of competition index values. The figure is based on the same set of model coefficients as in Figure 1. The key difference is that we are now 
varying our index of competition $\sigma$ and then plotting optimum quantities $q_{m}^{*}$ and $q_{d}^{*}$, along with welfare $W$ and the optimum tariff $t^{*}=(\tau-1)$. As can be seen in the figure, the optimal tariff rate falls with our market power index $\sigma$, as does welfare $W$ and domestic shipments $q_{d}$, while from equation (21) imports remain fixed. With the additional distortion in the market, in the form of an imperfectly competitive distribution sector, the welfare implications of trade policy become more complicated. It is evident that the optimal tariff declines with increasing concentration in services. Indeed, as illustrated in Figure 2, the optimal tariff when the service sector is a monopoly is a subsidy. In the absence of such an optimal tariff offset by the government, the more concentrated the service sector, the greater its exercise of its market power and, consequently, the lower the trade volume. A tariff further reduces the volume of trade, whereas a subsidy increases the level of imports and hence consumption. Such a subsidy benefits the service sector but, as their profits are part of national welfare, a welfare maximizing government would be prepared to offer it.

\section{FIGURE 2 ABOUT HERE}

We summarize the relationship between tariffs, profits, trade, and welfare in the following propositions:

Proposition 6. The optimum import tariff is a decreasing function of the degree of market power in the domestic trade and distribution sectors, and with a domestic service monopoly or cartel, the optimum tariff may actually be a subsidy.

Proposition 7. There is scope for either the private service sector (through markups) or the government (through tariffs) to exercise market power in international trade, with the optimum tariff implying direct substitution. 


\section{Market Access and the Exporter}

Consider the impact of alternative tariff and competition regimes for the exporter. If we are focused on quantity alone, then equations (8), (12) and (13) point to a negative relationship between tariffs and imperfect competition, on the one hand, and export volumes on the other. In addition, taking the cross-derivative from equation (13) we can see that the trade-volume effect of a tariff reduction depends on the underlying trade volume and hence on the degree of competition in the domestic distribution sector. To some extent, tariff reductions may simply lead to a greater exercise of market power by the domestic distribution sector (and vice-versa), nullifying expected direct benefits from tariff reductions in export markets. A second measure of the benefits of improved market access conditions is exporter producer surplus $P S$. Once again, this is simply the area of a triangle, in this instance the area between the inverse supply curve and the export price:

$$
P S=\frac{b_{d} H+y(H-G)}{2 A^{2}}
$$

From equation (23) we can calculate the welfare benefit to exporters of improved market access as manifested through increases in export quantities as being simply:

$$
\frac{d P S}{d \tau}=-\frac{K\left(b_{m} J+a_{m} y b_{d}\right)}{2 A^{2}}<0
$$

Further manipulation then confirms that the $P S$ benefit of tariff reductions is a decreasing function of the underlying market power of the service sector.

$$
\frac{d^{2} P S}{d \tau d \sigma}=\frac{K\left(b_{m} J+a_{m} y b_{d}\right)}{2 \sigma A^{2}}>0
$$

We summarize this section with the following propositions.

Proposition 8. The market-access benefits of tariff reductions in export markets are 
inversely related to the degree of market power exercised by the domestic trade and distribution sector in the export market.

Proposition 9. The benefits of market access concessions can be offset by increases in the degree of market power exercised by the domestic trade and distribution sector in the export market.

The first of these propositions formalizes the dependence of goods market integration in the European Union (recall the EU autos exemption) on distribution sector competition. The second goes directly to the heart of the Fuij-Kodak dispute. To use a technical GATT/WTO term, nullification and impairment can follow from changes in domestic regulation of the distribution sector.

\section{The Non-Linear Case}

In this section we offer a generalization of the basic trade volume results - Propositions 3,4 , and 5 - to the case of non-linear import demand and supply schedules. This provides a logical bridge to standard bilateral gravity modeling of trade volumes, where bilateral import volumes are a non-linear (and usually CES-based) function of demand and supply conditions. We focus strictly on the market for imports $q_{m}$. We start with the inverse supply function for imports as a function of $q_{m}$ :

$$
p_{c i f}=S\left(q_{m}\right), \quad S^{\prime}\left(q_{m}\right)>0
$$

Landed prices are still defined by a version of equation (2).

$$
p_{m}=\tau p_{c i f} \quad \text { where } \tau \equiv(1+t)
$$


Import demand is inversely related to price as defined in equation (28).

$$
p_{m}=D\left(q_{m}\right), \quad D^{\prime}\left(q_{m}\right)<0
$$

Profit for a representative firm $j$ in the intermediate service sector will be as shown in equation (29).

$$
\pi_{j}=\left[D\left(q_{m}\right)-\tau S\left(q_{m}\right)-c\right] q_{m j}
$$

From the first order conditions for maximization of equation (29), if we apply CournotNash assumptions, including quantity competition and symmetry, and define market supply and demand elasticities as $\varepsilon^{D}$ and $\varepsilon^{S}$, then we get the usual equality between perceived marginal revenue and perceived marginal cost:

$$
D\left(q_{m}\right)\left(1+\frac{\sigma}{\varepsilon^{D}}\right)=S\left(q_{m}\right)\left(1+\frac{\sigma}{\varepsilon^{S}}\right)+c
$$

Differentiating equation (30) with respect to market power, and assuming that elasticities are (locally) constant, we can obtain the response of equilibrium quantities to tariffs and market power.

$$
\begin{gathered}
D^{\prime}\left(q_{m}\right)\left(1+\frac{\sigma}{\varepsilon^{D}}\right) d q_{m}+D\left(q_{m}\right) \frac{d \sigma}{\varepsilon^{D}}=S^{\prime}\left(q_{m}\right) \tau\left(1+\frac{\sigma}{\varepsilon^{S}}\right) d q_{m}+S\left(q_{m}\right) \tau \frac{d \sigma}{\varepsilon^{S}} \\
\Rightarrow \frac{d q_{m}}{d \sigma}=\frac{\frac{S\left(q_{m}\right) \tau}{\varepsilon^{S}}-\frac{D\left(q_{m}\right)}{\varepsilon^{D}}}{D^{\prime}\left(q_{m}\right)\left(1+\frac{\sigma}{\varepsilon^{D}}\right)-S^{\prime}\left(q_{m}\right) \tau\left(1+\frac{\sigma}{\varepsilon^{S}}\right)}<0 \\
D^{\prime}\left(q_{m}\right)\left(1+\frac{\sigma}{\varepsilon^{D}}\right) d q_{m}=S^{\prime}\left(q_{m}\right) \tau\left(1+\frac{\sigma}{\varepsilon^{S}}\right) d q_{m}+S\left(q_{m}\right)\left(1+\frac{\sigma}{\varepsilon^{S}}\right) d \tau \\
\Rightarrow \frac{d q_{m}}{d \tau}=\frac{S\left(q_{m}\right)\left(1+\frac{\sigma}{\varepsilon^{S}}\right)}{D^{\prime}\left(q_{m}\right)\left(1+\frac{\sigma}{\varepsilon^{D}}\right)-S^{\prime}\left(q_{m}\right) \tau\left(1+\frac{\sigma}{\varepsilon^{S}}\right)}<0 .
\end{gathered}
$$


Equations (31) and (32) yield the following generalization of equations (12) and (13).

$$
q_{m}=M(\sigma, \tau) M_{\sigma}, M_{\tau}<0
$$

Note that while equations (12) and (13) and the associated Propositions 3 and 4 generalize to the non-linear case, equation (14) and associated Propositions 5 do not. In particular, if we start from equation (32), we can derive the following expression.

$$
\begin{aligned}
\frac{d^{2} q_{m}}{d \tau d \sigma} & =\left\{\frac{S}{\varepsilon^{s}\left(D^{\prime}\left(\left(\varepsilon^{d}+\sigma\right)\left(\varepsilon^{d}\right)^{-1}\right)-S^{\prime}(q)\left(\varepsilon^{s}+\sigma\right)\left(\varepsilon^{s}\right)^{-1}\right)}\right\} \\
& -\left\{\frac{S\left(\left(\varepsilon^{s}+\sigma\right)\right)\left(D^{\prime}\left(\varepsilon^{d}\right)^{-1}-S^{\prime}\left(\varepsilon^{s}\right)^{-1}\right)}{\varepsilon^{s}\left(D^{\prime}\left(\left(\varepsilon^{d}+\sigma\right)\left(\varepsilon^{d}\right)^{-1}\right)-S^{\prime}\left(\varepsilon^{s}+\sigma\right)\left(\varepsilon^{s}\right)^{-1}\right)^{2}}\right\} \\
& +\left\{\left(\left(\varepsilon^{s}+\sigma\right)\left(\varepsilon^{s}\right)^{-1}\right)\left(S^{\prime}-S \frac{\left(D^{\prime \prime}\left(\left(\varepsilon^{d}+\sigma\right)\left(\varepsilon^{d}\right)^{-1}\right)-S^{\prime \prime}\left(\varepsilon^{s}+\sigma\right)\left(\varepsilon^{s}\right)^{-1}\right)}{\left(D^{\prime}\left(\left(\varepsilon^{d}+\sigma\right)\left(\varepsilon^{d}\right)^{-1}\right)-S^{\prime}\left(\varepsilon^{s}+\sigma\right)\left(\varepsilon^{s}\right)^{-1}\right)^{2}}\right) \frac{\partial q}{\partial \sigma}\right\}
\end{aligned}
$$

The general version of equation (34) has ambiguous sign, though we can easily sign this condition in the linear case. In the linear case, differentiating equation (31) with respect to $\tau$ then leads directly to a version of equation (14). In more general terms, the impact on trade volumes depends on underlying price sensitivity of import demand and supply schedules. We summarize these points as follows:

Proposition 10. In the general case of non-linear import supply and demand, international trade volumes are inversely related to the degree of concentration in the domestic trade and distribution sector, or alternatively the degree of market power exercised in the domestic sector. (Equation 31)

Proposition 11. In the general case of non-linear import supply and demand, international trade volumes are inversely related to tariffs controlling for the degree of concentration in the domestic trade and distribution sector. (Equation 32) 
Proposition 12. In the general case of non-linear import supply and demand, the interaction of the effects of tariffs and concentration on trade volumes is ambiguos. Where it follows the linear case in sign, and also where import supply is sufficiently elastic relative to import demand, the negative impact of market power on trade volumes is greatest in a zero tariff context, and its marginal impact falls with increased levels of trade. Critically, this sign depends on relative elasticities. (Equation 34)

\section{Empirics}

We turn next turn to estimating a standard reduced form gravity equation of bilateral trade flows, based on tariffs, distance, and exporter-specific dummies for a cross-section. (See for example Disidier and Head 2003 and Anderson and van Wijncoop 2003.) We augment the standard form by including measures of distribution sector competition, with emphasis on the extent to which the basic effects we have discussed, imperfect competition in distribution affecting market access in goods as summarized on Propositions 10, 11, and 12, matter - statistically and economically - for trade volumes.

Our basic data for this exercise are summarized in Table 1. From the OECD (2000), we work with two estimates of the degree of competition in the road freight and retail distribution for some, but not all, OECD members. This includes an index of barriers to entry in the sector, and also what can be interpreted as an overall or composite index of the degree of competition in the sector. These estimates provide a single set of indexes for each importer. For trade, we work with bilateral merchandise trade data extracted from UNCTAD's COMTRADE database. We have matched these to to bilateral import protection data for 2001 from CEPII and GTAP (2005). The protection data offer the advantage of including a bottom-up concordance (though for a single year) from detailed tariff data to aggregate bilateral trade flows, including preferential tariff rates. They also include estimates of the trade-tax equivalent of export barriers as part of the 
basic trade barrier data (primarily the quota regime on textiles and clothing). Working with these data lets us exploit interaction between protection and competition in the sample. In addition, bilateral export data have been adjusted to reflect estimated freight margins. For 69 countries as exporters, we have matched bilateral import data to other country-specific data for the 22 OECD importers covered by our set of OECD indexes on the distribution and freight sectors. We also incorporate data on distance, common language, and common borders from Guillaume, Mayer and Zignago (2004). Finally, as we are unable to use importer dummies for this exercise, we also include data on importer GDP and per-capita income from the World Bank (2005), following the older (pre fixed effects) gravity literature. After matching trade data to our competition data, we have 1,725 bilateral trade flows to work with involving OECD countries as importers in 2001.

Our estimating equation is a reduced-form gravity equation, utilizing the data discussed above and augmented to reflect Propositions 10, 11, and 12 and equation (33). Using exporter dummies controls for $f o b$ prices, while value flows map to quantities if we normalize these prices to unity. Defining imports by country $j$ from country $i$ as $M_{i, j}$, we work with the following estimating equation.

$$
\begin{aligned}
q_{m, i, j} & =\alpha_{0}+\alpha_{1} \ln \left(G D P_{j}\right)+\alpha_{2} \text { Dist }_{i, j}+\alpha_{3} \ln \left(\tau_{i, j}\right)+\alpha_{4} L A N G_{i, j} \\
& +\alpha_{5} B O R D E R_{i, j}+\alpha_{6} \ln \left(\text { Index }_{j}\right)+\alpha_{7}\left[\ln \left(\text { Index }_{j}\right) \ln \left(\tau_{i, j}\right)\right] \\
& +\alpha_{8}\left[\ln \left(P C I_{i}\right) \ln \left(\text { Index }_{j}\right) \ln \left(\tau_{i, j}\right)\right] \\
& +\sum_{i} \alpha_{9, i} D_{i}+\alpha_{10} N A F T A_{i, j}+\alpha_{11} E E A_{i, j}+\alpha_{12} \ln \left(P C I_{j}\right)+\varepsilon_{i, j}
\end{aligned}
$$

The $D_{i}$ terms are dummy variables assigned to each exporter, to reflect the set of exporter-specific variables that remain fixed across importers. These control for exporter characteristics, including the level of per capita income for the exporter (which also enters in interaction form with $\alpha_{8}$ ). The variables $N A F T A_{i, j}$ and $E E A_{i, j}$ are also dummies, 
capturing joint membership in either the North American or European free trade bloc. The terms Dist $t_{i, j}$ and $\tau_{i, j}$ measure bilateral distance and import barriers (a combination of trade-weighted import tariffs and trade tax equivalents of export restraints) as a share of total import value. We expect the coefficients applied to these variables $\alpha_{2}$ and $\alpha_{3}$ to both be negative. Translating $q$ in the import equation (33) to imports $q$ in equation (35), the coefficients $\alpha_{6}$ and $\alpha_{3}$ in equation (35) correspond to the terms $M_{\sigma}$ and $M_{\tau}$ in equation (33). They also map directly fo the partial derivatives expressed in equations (12) and (13). Recall that the Index term is meant to capture the effects related to $\sigma$ in the discussion above. From the expressions in (8), we expect $\alpha_{6}$ to be negative as well. Our own expectation is that the interaction term $\alpha_{7}$ will be positive, based on equation (13) and Proposition 5, though from equation (32) and Proposition 12 there is technically an ambiguity. We have also included the interaction term $\alpha_{8}$ to allow for possible variations in the impact of tariff and competition-related barriers depending on the level of development of the trading partner. We explore this issue further below with split-sample regressions.

Table 2 presents robust regression results for equation (35), based on both versions of our competition index. ${ }^{7}$ Relevant coefficients are significant in the 0.05 to 0.01 range or better, with the sign predicted from our theoretical analysis for the direct effect from competition. (Where we have expectations of sign, the one-tailed significance results in the table are appropriate. This includes both competition indexes.) An F-test for the joint significance of the competition coefficients $\alpha_{6}$ and $\alpha_{7}$ rejects the null hypothesis

\footnotetext{
${ }^{7}$ We have reported robust regression results because the Breusch-Pagan (1979) Chi-squared test statistic (as implemented in STATA) leads us to reject the hypothesis of homoscedasticity at any conceivably reasonable level of significance. Further examination with Szroeter's (1978) test statistic points to a pervasive problem, involving roughly half of the right hand side variables. Many of these relate to the exporter fixed effect variables, indicating for example greater variance in the data involving some exporting countries than others. This is not surprising, as we have included relatively small aggregate trade flows (all flows over $\$ 10,000$ ), usually involving a range of least developing countries. In these cases, bilateral trade flows may be a function of historical/structural variables unique to a given country pairing. Given the pervasiveness of the problem, there is a not an obvious single adjustment to be made to the data. We therefore resort to robust least squares, involving Huber-type (1981) robust regressions as implemented in STATA. These results are what are shown in Tables 2 and 3.
} 
that the coefficients are jointly zero at the .001 level. Country fixed-effect coefficients are not shown, though they are all generally significant at the 0.001 level across all regressions. The pattern of results for competition fits expectations. Basically, these results suggest that tariffs and reduced competition both have a dampening effect on estimated trade flows, consistent with our theory-based propositions in the previous sections of this paper.

Table 3 presents a further decomposition of patterns in the data, based on splitsample regressions. Implicit in the analysis above is that competition matters more as importers have more market power. In terms of the previous section, this depends on the relative slopes of the supply and demand schedules, in conjunction with the general level of competition in the service sector itself. In a more general sense, we may expect importing/distribution firms to have more market power vis-à-vis smaller suppliers. At the same time, exporters in lower income countries may be less organized, and less adept, in holding their own against market power exercised by buyers. (Imagine WalMart negotiating supplier contracts in Jamaica, as opposed to in Canada.)

In Table 3 we explore this issue by making the following splits in the data. The first split involves OECD trade with low-income countries (defined as having a per-capita income below $\$ 1000$ in 2001 dollars), and all other trade. For the second split, we divide the sample into OECD trade where the importer is large (with a nominal GDP greater than \$500billion) and the exporter is small (defined as having a nominal GDP below $\$ 100$ billion), versus all other trade. For the final split, we examine OECD trade where the importer is large and the exporter is both poor and small. In all cases, we find that the correlation in the data between exports to the OECD and competition is greater when there is likely to be greater market power, in the sense that it matters more for smaller and poorer exporters. The structure of the retail and distribution sector in the OECD countries is more of a trade barrier for small and low-income countries than it is for exporters from higher income and larger economies. 
Finally, we turn to marginal effects given the range of values for our competition index in the sample. In particular, in Table 4 we have used the example of intra-EU trade (where tariffs are zero) to convey a sense of the potential impact of retail markups on trade when tariffs are reduced. The emphasis here is not so much significance in a statistical sense, but rather an economic one. In the table, we have taken the tariff coefficient from Table 2, combined with sample values for EU competition indexes and a competition coefficient estimated for the intra-EU15 subset of our full sample. We have used these to calculate a trading cost- or tariff-equivalent from changing the degree of competition in the sample of EU countries, for intra-EU (i.e. duty-free) trade. Hence, for example, from the first column of numbers in Table 4, moving France to the average level of competition in the distribution sector that prevails across the EU would be comparable to eliminating a 4.2 percent tariff against its EU partners. Put another way, the current regime in France has the same impact as having an "average" competitive regime, combined with a tariff on intra-EU imports of 4.2 percent. Moving France to the most competitive level in the sample would correspond to the elimination of an 8.4 percent tariff. In the table, these trading cost equivalents range between 0.0 and 8.4 percent of the value of trade, with most between 3.0 and 4.0 percent of the value of trade. What this means is that a substantial share of the trade-related benefits of duty-free trade in the EU (especially for consumer products most affected by retail and distribution margins) may be undercut in some countries by problems linked to competition in the retail and distribution sectors. Similar concerns may be raised in other low tariff regimes, as with the Japanese tariff regime. ${ }^{8}$

The patterns of results in Tables 2, 3, and 4 suggest that variations in the degree of

\footnotetext{
${ }^{8}$ See the discussion of Kodak-Fuji elsewhere in this paper. Indeed, our estimates, when focusing on marginal impacts and sample averages, are consistent with regimes offering approximately symmetric offsets between market access gains from tariff reductions and market access loss from corresponding increased markups in distribution. In formal terms, taking average sample values in Table 1 and the coefficients in Table 2 and constructing confidence intervals reflecting the tariff, index, and interaction coefficients, the resulting bounded range of marginal effects includes such outcomes as fitting within the ranges observed for tariffs and competition.
} 
domestic competition matters for trade. Indeed, problems with competition in domestic distribution and trade activities are likely to themselves act as barriers to trade. In a European context, this means that continued competition exemptions for automobiles, for example, should indeed be expected to hinder trade substantially. In the context of multilateral negotiations in the World Trade Organization (WTO), this also means that WTO-based liberalization of these service sectors under the GATS (General Agreement on Trade in Services) may also mean improved market access conditions for affected goods sectors along the lines developed here. More broadly, this supports the notion that the benefits of trade for exportering countries is a function of their market power vis-à-vis trade and distribution firms in the importing countries. At the same time, increased FDI flows in the service sectors leading to increased concentration and less rather than more competition in distribution and trade services, ironically may lead to an erosion of market access for goods, both in a customs union and bilateral setting. It may also erode multilateral concessions on market access for goods.

\section{Summary and Conclusions}

The pattern of trade in goods depends on a number of factors. Recent work has stressed transport costs and its linkages to the geography of production and trade. We take a different slant here. In this paper we examine the interaction between trade in goods and the degree of market power exercised by the domestic trade and distribution sectors the so-called margin sectors. We develop an analytical model that allows us to highlight interactions between the degree of competition in domestic service sectors and the pattern of trade in goods, followed by an econometric exercise involving the import patterns of the OECD countries vis- á-vis its partners. Our analytical results point to an expected linkage between service sector competition and goods trade. The domestic service sector can serve as an effective import barrier. This is also supported by our econometric 
results. These point to statistically significant linkages between effective market access conditions for goods and the structure of the service sector. From back of the envelope calculations, they also point to economically/qualitatively significant effects. (See the discussion pertaining to Table 4.) What all this means is that, by ignoring the structure of the domestic service sector, we may be seriously overestimating the market access benefits of actual tariff reductions given the existence of imperfect competition in the margin sectors. We also find that the degree of competition in margin sectors in destination markets matters more for those exporters in poor and small countries than those in other countries. Finally, our results suggest that GATS-based services liberalization may boost goods trade as well, if it leads to more competition in the distribution and trade sectors. Where GATS-based liberalization involves FDI and increased concentration, such service sector liberalization may instead have the unintended effect of eroding market access conditions for goods. 


\section{References}

Anderson, J. And E. van Wincoop (2003), "Gravity with Gravitas: A Solution to the Border Puzzle," American Economic Review 93(1): 170-192.

Breusch, T.S. and A.R. Pagan (1979), "A Simple Test for Heteroscedasticity and Random Coefficient Variation," Econometrica 47: 1287-1294.

Disdier, A.C. And K. Head (2003), "Exaggerated Reports on the Death of Distance: Lessons from a Meta-Analysis," working paper, TEAM, Université de Paris I Panthéon Sorbonne.

Flam, H., And H. Nordström (1995), "Why Do Pre-Tax Prices Differ so much across European Countries," CEPR Discussion Paper No. 1181.

Francois, J.F. (1990), "Producer Services, Scale, and the Division of Labor," Oxford Economic Papers 42: 715-729.

Francois, J.F. And H. Horn (2007), "Antitrust in Open Economies," in V. Ghosal and J. Stennek, eds., The Political Economy of Antitrust, Elsevier-North Holland.

Francois, J.F. And J. Woerz (2008), "Producer Services, Manufacturing Linkages, and Trade, " Journal of Industry, Competition and Trade, 8(3): 199-229.

Francois, J.F. M. Manchin and H. Norberg (2008), "Distribution services and differential producer and consumer price impacts of trade, " paper presented at the 2008 European Trade Study Group annual meetings, Warsaw.

Francois, J.F. And B. Hoekman (2009), "Services Trade and Policy, " CEPR discussion paper.

Guillaume, G., T. Mayer and S. Zignago (2004), "Notes on CePII's distance measures," CEPII discussion paper, March. 
Global Trade Analysis Project (2005), The GTAP Database version 6: publicrelease version, GTAP consortium, Purdue University.

HeAD, K. AND J. RIEs (1997), "International Mergers and Welfare under Decentralized Competition Policy," Canadian Journal of Economics:30(4), 1104-23.

Hoekman, B. And H.L. KeE (2007), "Imports, Entry and Competition Law as Market Disciplines, " European Economic Review 51(4): 831-858.

Hoekman, B. And P. Mavroidis (1994), "Competition, Competition Policy and the GATT," The World Economy 17(2): 121150.

Horn, H. (2006), "National Treatment in the GATT," American Economic Review 96(1): 394-404.

Horn, H. And J. Levinsohn (2001), "Merger Policies and Trade Liberalization," The Economic Journal 111(April): 244-276.

Horn, H, And and P.C. Mavroidis (2001), "Economic and Legal Aspects of the Most-Favored-Nation Clause," European Journal of Political Economy 17(2): 233-279.

Huber, P. (1981), Robust Statistics, John Wiley \& Sons: New York: 153-199.

Ito, T. and A.O. Krueger editors (2003), Trade in Services in the Asia-Pacific Region: NBER-East Asia Seminar on Economics, Volume 11, Chicago and London: University of Chicago Press, 2003.

Rutherford, T., J. Jensen And D. TARr (2007), "The impact of liberalizing barriers to foreign direct investment in services: the case of Russian accession to the World Trade Organization," Review of Development Economics 11:3.

Lutz, M. (2004), "Pricing in Segmented Markets, Arbitrage Barriers and the Law of One Price: Evidence from the European Car Market," Review of International Economics 12(3): 456-475. 
Markusen, J.R. (1989), "Trade in Producer Services and in Other Specialized Intermediate Inputs, " American Economic Review 79: 85-95.

Markusen, J., T. Rutherford and D. Tarr (2005), "Trade and Direct Investment in Producer Services and the Domestic Market for Expertise, " Canadian Journal of Economics 38(3): 758-777.

Nanto, N. (1998), "The Kodak-Fuji Film Trade Dispute at the WTO," Congressional Research Service: Washington.

OECD (2000), "Regulatory Reform in Road Freight and Retail Distribution," paper ECO/WKP (2000)28, Paris.

Olarreaga, M. and C. Ozden 2005, "AGOA and Apparel: Who Captures the Tariff Rent in the Presence of Preferential Market Access?" World Economy 28(1): 63-77.

Rutherford, T. AND D. TARr (2007).,"Poverty effects of RussiasWTO accession: modeling real households and endogenous productivity effects, "Journal of International Economics: forthcoming.

Szroeter, J. (1978), "A Class of Parametric Tests for Heteroscedasticity in Linear Econometric Models," Econometrica 46: 1311-1327.

World BANK (2005), World Development Indicators, Washington DC.

YEAPLE, S.R. (2006), "Offshoring, Foreign Direct Investment, and the Structure of U.S. Trade" Journal of the European Economic Association, 4(2-3): 602-611. 
Table 1

Database Overview (Value Data Reported in logs)

\begin{tabular}{|c|c|c|c|c|}
\hline name & description & mean & $\max$ & $\min$ \\
\hline$G D P$ & $\begin{array}{l}\text { Importer gross domestic product in } \\
\text { billions of dollars in } 2001 \\
\text { Source: World Bank (2005). }\end{array}$ & 12.797 & 16.126 & 10.858 \\
\hline$P C I$ & $\begin{array}{l}\text { PPP-based per-capita income, dollars, } 2001 . \\
\text { Source: World Bank (2002). }\end{array}$ & 9.675 & 10.517 & 7.709 \\
\hline$M$ & $\begin{array}{l}\text { Imports, millions of U.S. dollars in } 2001 . \\
\text { Source: UNCTAD COMTRADE database }\end{array}$ & 4.695 & 12.011 & -4.605 \\
\hline$\tau=1+t$ & $\begin{array}{l}\text { MFN trade-weighted tariff (adjusted } \\
\text { for trade preferences and NTBs where available) } \\
\text { based on a concordance of WTO, } \\
\text { UNCTAD, and MACMAPS tariff data . } \\
\text { Source: WITS \& CEPII. }\end{array}$ & 0.028 & 0.670 & -0.123 \\
\hline Dist & $\begin{array}{l}\text { Distance between national capitals, from } \\
\text { the CEPII database of distance measures. } \\
\text { Source: Gaulier, Mayer, and Zignago (2004). }\end{array}$ & 8.332 & 9.884 & 2.821 \\
\hline Border & $\begin{array}{l}\text { Sharing a common border. } \\
\text { Source: Gaulier, Mayer, and Zignago (2004). }\end{array}$ & 0.041 & 1.000 & 0.000 \\
\hline Lang & $\begin{array}{l}\text { Sharing a common language } \\
\text { Source: Gaulier, Mayer, and Zignago (2004). }\end{array}$ & 0.059 & 1.000 & 0.000 \\
\hline Index 1 & $\begin{array}{l}\text { Overall index of competition in the } \\
\text { freight/distribution sectors. } \\
\text { Source: OECD (2000). }\end{array}$ & 0.735 & 1.548 & -0.223 \\
\hline Index 2 & $\begin{array}{l}\text { Index of barriers to entry in the } \\
\text { freight/distribution sectors. } \\
\text { Source: OECD (2000). }\end{array}$ & 0.747 & 1.705 & -0.357 \\
\hline$N A F T A$ & $\begin{array}{l}\text { A dummy variable for the case where } \\
\text { importer and exporter are both in } \\
\text { the North American Free Trade Area. }\end{array}$ & 0.005 & 1.000 & 0.000 \\
\hline$E E A$ & $\begin{array}{l}\text { A dummy variable for the case where } \\
\text { importer and exporter are both in the } \\
\text { the European Economic Area. }\end{array}$ & 0.221 & 1.000 & 0.000 \\
\hline
\end{tabular}

Note: The scale of competition indexes in levels ranges from $0-6$, for least to most restrictive regimes. For countries reported as an interval by the OECD, the mid-point has been used. Index data are available for 22 OECD countries. Trade data are grouped by these 22 importers and by 69 exporting countries. Applied tariff data and distance data have been matched to these bilateral trade pairs. 
Table 2

Robust Regressions: Gravity Equation of Bilateral Trade

\begin{tabular}{|c|c|c|}
\hline & $\begin{array}{c}\text { model } 1 \\
\text { general index } \\
\text { of competition }\end{array}$ & $\begin{array}{c}\frac{\text { model } 2}{\text { index of }} \\
\text { entry barriers }\end{array}$ \\
\hline$\alpha_{1}: G D P_{j}$ & $\begin{array}{c}0.973 \\
(56.92)^{* * *} \\
\end{array}$ & $\begin{array}{c}0.984 \\
(54.53)^{* * *} \\
\end{array}$ \\
\hline$\alpha_{2}:$ Dist $_{i, j}$ & $\begin{array}{c}-1.056 \\
-(28.58)^{* * *}\end{array}$ & $\begin{array}{c}-1.043 \\
-(28.19)^{* * *}\end{array}$ \\
\hline$\alpha_{3}: \ln \left(\tau_{i, j}\right)$ & $\begin{array}{c}-2.246 \\
-(3.79) * * *\end{array}$ & $\begin{array}{c}-2.724 \\
-(4.60)^{* * *}\end{array}$ \\
\hline$\alpha_{4}: L A N G_{i, j}$ & $\begin{array}{c}0.604 \\
(7.26)^{* * *}\end{array}$ & $\begin{array}{c}0.596 \\
(7.21)^{* * *}\end{array}$ \\
\hline$\alpha_{5}: B O R D E R_{i, j}$ & $\begin{array}{l}-0.030 \\
-(0.27)\end{array}$ & $\begin{array}{l}0.014 \\
(0.13)\end{array}$ \\
\hline$\alpha_{6}: \ln \left(\right.$ Index $\left._{j}\right)$ & $\begin{array}{c}-0.311 \\
-(7.93) * * *\end{array}$ & $\begin{array}{c}-0.280 \\
-(8.39)^{* * *}\end{array}$ \\
\hline$\alpha_{7}:\left[\ln \left(\operatorname{Index} x_{j}\right) \ln \left(\tau_{i, j}\right)\right]$ & $\begin{array}{c}5.33 \\
(1.18) \dagger\end{array}$ & $\begin{array}{c}9.22 \\
(2.57)^{* * *}\end{array}$ \\
\hline$\alpha_{8}:\left[\ln \left(P C I_{i}\right) \ln \left(\right.\right.$ Index $\left.\left._{j}\right) \ln \left(\tau_{i, j}\right)\right]$ & $\begin{array}{c}-0.908 \\
-(1.70)^{*}\end{array}$ & $\begin{array}{c}-1.368 \\
-(3.19)^{* * *}\end{array}$ \\
\hline$\alpha_{10}: N A F T A_{i, j}$ & $\begin{array}{c}0.597 \\
(1.82)^{*}\end{array}$ & $\begin{array}{c}0.615 \\
(1.88)^{*}\end{array}$ \\
\hline$\alpha_{11}: E E A_{i, j}$ & $\begin{array}{l}-0.102 \\
-(0.96) \\
\end{array}$ & $\begin{array}{l}-0.152 \\
-(1.43) \\
\end{array}$ \\
\hline$\alpha_{12}: P C I_{j}$ & $\begin{array}{c}-0.058 \\
-(1.95)^{*} \\
\end{array}$ & $\begin{array}{c}-0.10 \\
-(3.16)^{* * *} \\
\end{array}$ \\
\hline $\begin{array}{l}\text { Summary statistics for estimates from robust regressions } \\
\text { variables } \\
\text { observations } \\
\text { df } \\
F: H_{0}\left(\alpha_{0}=\alpha_{1}=\ldots=\alpha_{11}=0\right), \operatorname{Pr}>F \\
\end{array}$ & $\begin{array}{c}79 \\
1701 \\
1621 \\
326.62,0.0\end{array}$ & $\begin{array}{c}79 \\
1633 \\
1553 \\
318.54,0.0 \\
\end{array}$ \\
\hline$R^{2}$ (from corresponding OLS regression) & 0.9156 & 0.9159 \\
\hline
\end{tabular}

Note: Robust regressions are estimating using Huber method as implemented in STATA, with default convergence criteria. $t$-statistics are reported in parentheses $\dagger, *, * *$, and $* * *$ indicating $0.15,0.10,0.05$, and 0.01 levels of significance for a two-tailed test, or $0.075,0.05,0.025$, and 0.005 where a one-tailed test is instead appropriate, as discussed in the text. 
Table 3, Robust Regression Estimates Competition Coefficients with Split Samples

\begin{tabular}{|c|c|c|}
\hline & $\begin{array}{c}\text { model } 1 \\
\text { general index } \\
\text { of competition }\end{array}$ & $\begin{array}{c}\text { model } 2 \\
\text { index of } \\
\text { entry barriers }\end{array}$ \\
\hline Exporter is poor & $\begin{array}{c}-0.339 \\
-(3.72)^{* * *} \\
\end{array}$ & $\begin{array}{c}-0.328 \\
-(4.43)^{* * *} \\
\end{array}$ \\
\hline Rest of Sample & $\begin{array}{c}-0.271 \\
-(6.46)^{* * *}\end{array}$ & $\begin{array}{c}-0.193 \\
-(5.78)^{* * *}\end{array}$ \\
\hline A Large importer and a small exporter & $\begin{array}{c}-0.366 \\
-(4.65) * * * \\
\end{array}$ & $\begin{array}{c}-0.269 \\
-(4.48)^{* * *} \\
\end{array}$ \\
\hline Rest of Sample & $\begin{array}{c}-0.286 \\
-(6.93)^{* * *}\end{array}$ & $\begin{array}{c}-0.239 \\
-(6.77)^{* * *}\end{array}$ \\
\hline A Large importer and a small, poor exporter & $\begin{array}{c}-0.327 \\
-(2.46) * * * \\
\end{array}$ & $\begin{array}{c}-0.299 \\
-(2.75)^{* * *} \\
\end{array}$ \\
\hline Rest of Sample & $\begin{array}{c}-0.279 \\
-(7.00)^{* * *}\end{array}$ & $\begin{array}{c}-0.208 \\
-(6.43)^{* * *}\end{array}$ \\
\hline
\end{tabular}

Note: Robust regressions are estimating using Huber method as implemented in STATA, with default convergence criteria. $t$-statistics are reported in parentheses $\dagger,{ }^{*}, * *$, and $* * *$ indicating $0.15,0.10,0.05$, and 0.01 levels of significance for a two-tailed test, or $0.075,0.05,0.025$, and 0.005 where a one-tailed test is instead appropriate, as discussed in the text. 
Table 4

Trade-cost Equivalents for Intra-EU Trade for Changes in Competition in Member States, \%

\begin{tabular}{|l|c|c|}
\hline & $\begin{array}{c}\text { move to average } \\
\text { EU regime }\end{array}$ & $\begin{array}{c}\text { move } \text { most } \\
\text { competitive } \\
\text { EU regime }\end{array}$ \\
\hline Austria & -3.4 & -7.5 \\
Denmark & -1.3 & -5.3 \\
Finland & -1.5 & -5.6 \\
France & -4.2 & -8.4 \\
Germany & 3.9 & 0.0 \\
Great Britain & -0.4 & -4.4 \\
Greece & -0.4 & -4.4 \\
Ireland & 3.0 & -0.9 \\
Italy & -1.7 & -5.8 \\
Netherlands & 3.0 & -0.9 \\
Portugal & -0.6 & -4.7 \\
Spain & -0.4 & -4.4 \\
Sweden & 1.9 & -2.1 \\
\hline
\end{tabular}

Note: Based on competition index 1, Table 2 coefficient for tariffs, and a split-sample regression estimate of the competition index for the sub-sample of intra-EU trade. 


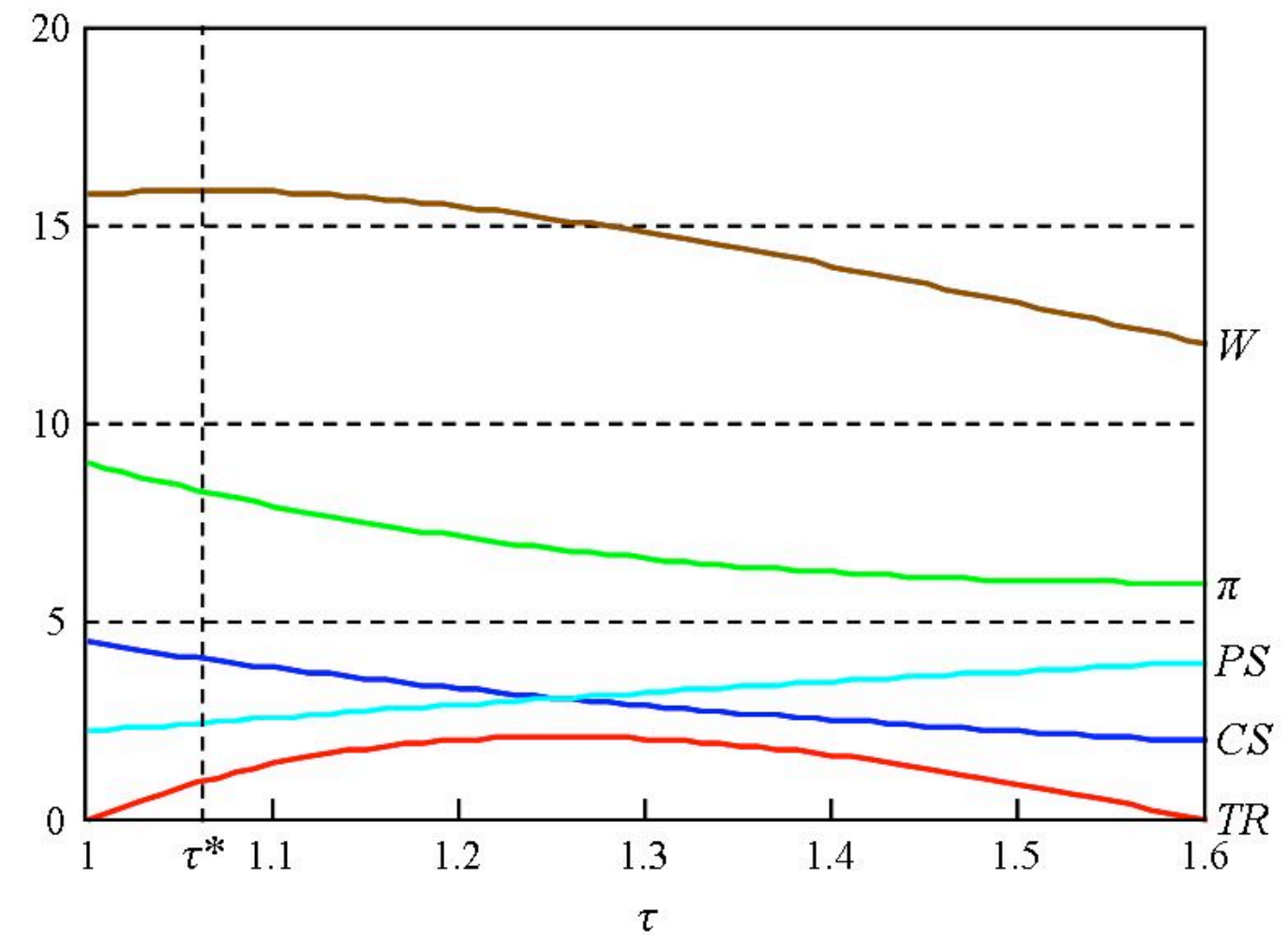

Figure 1: Welfare decomposition with varying rates of $\tau$

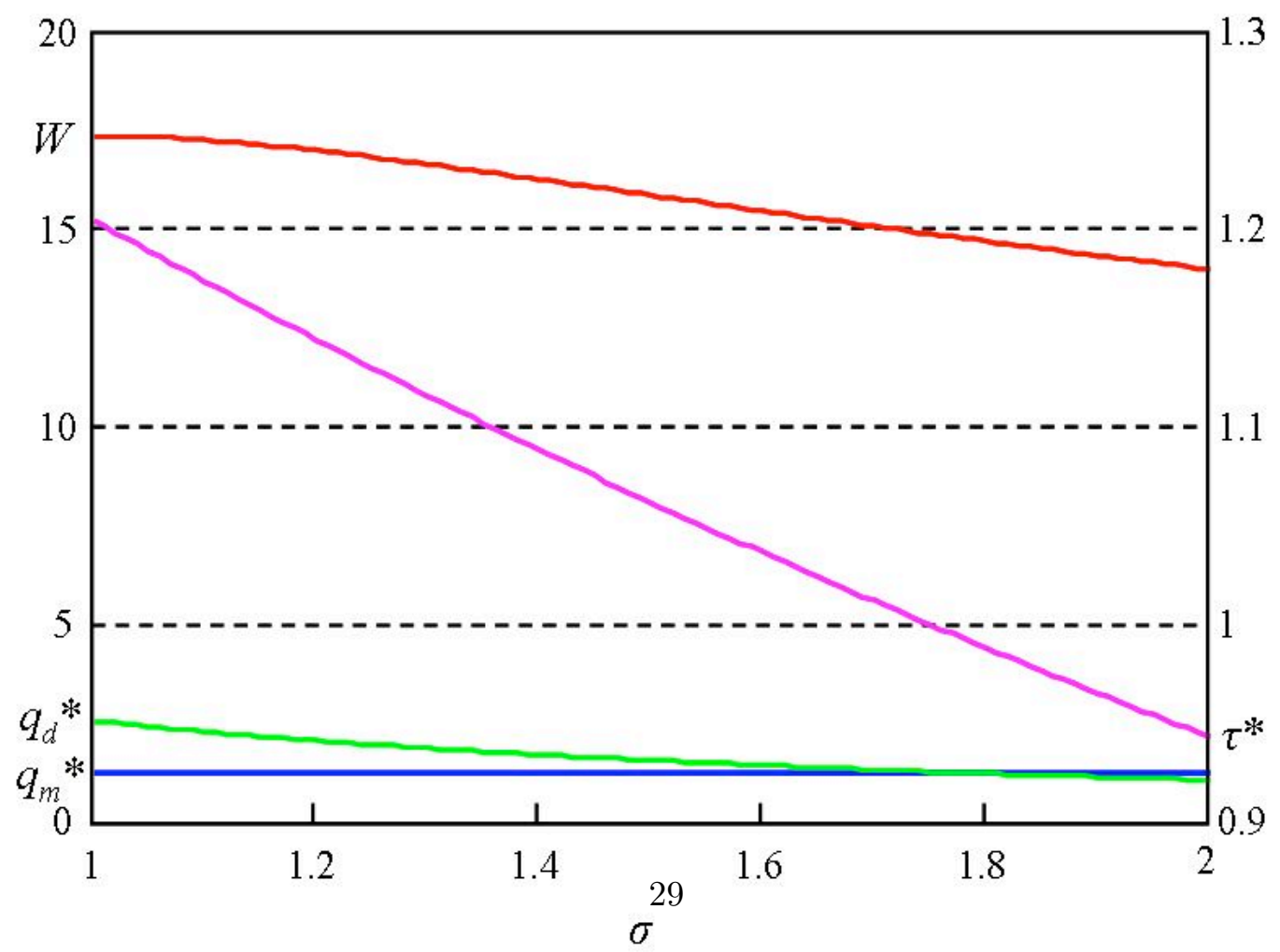

Figure 2: The optimal tariff and welfare when varying $\sigma$ 